\title{
Protective Effect of Moringa Oleifera Seeds Extract on Toxicity In Liver And Kidney Induced By Acetampride . \\ Mai T. hashem ${ }^{3}$, Farhat F. Ali' ${ }^{1}$, Mady M.A. ${ }^{2}$, Amr A. abd Alla ${ }^{3}$ \\ 1 Fac. of Agric. Chem. Dept. Benha Univ. Egypt. \\ 2 Fac. of Agric. Chem. Dept. Benha Univ. Egypt. \\ 3 Mammalian Toxic. Dept. cent. Agric. Pesticides Lab, Agric. Res. Cent. Ministry of agric. Egypt.
}

\begin{abstract}
The present study aimed to distinguish light on the protective of Moringa oleifera seeds dried ethanolic extract on the toxicity in liver and kidney induced by acetamprid pesticide which widely produced and used for agricultural treatment in Egypt. Physico-chemical parameters and identification of fatty acid composition of Moringa oleifera seeds oil were elvaluated. In addition, the biological effects of bioactive components of seeds dried extract at concentration $200 \mathrm{mg} / \mathrm{kg}$ b.w. oil as additives into the diets on kidney and liver functions, lipid profile ,serum glucose levels, hematological parameters and histopatholgical examination of experimental rats were evaluated. From the obtained results, it could be noticed that the total phenolic acid, flavonoids and tannin contents in Moringa oleifera seeds of the dried ethanolic extract were $44.25 \pm 1.13,114.36 \pm 0.72$ and $20.77 \pm 1.10 \mathrm{ug} / \mathrm{g}$, respectively. Total antioxidant capacity of dried ethanolic extract of Moringa oleifera seeds was found to be $143.29 \pm 0.37,178.10 \pm 2.18$ , 189.18 \pm 2.06 and $222.47 \pm 0.81$ at $50,100,150$ and $200 \mathrm{ug} / \mathrm{ml}$. Also, the results showed that the Moringa oleifera (MO) seeds oil extract was dominated by the high percentage of total unsaturated fatty acid $(80.29 \%)$ than its saturated $(19.71 \%)$. On the other hand, the results showed that there were significant increasment of biochemical parameters such as serum urea and creatinine (as function of kidney), as well as ALT and AST activity also albumin and total protein (as function of liver), total cholesterol, triglyceride and serum glucose levels of the experimental rats. These values were found significantly decreased in all treatments rats fed diets containing MO seeds oils extract at dose of $200 \mathrm{mg} / \mathrm{ml} \mathrm{b.w.} \mathrm{as} \mathrm{compared} \mathrm{with} \mathrm{the} \mathrm{group} \mathrm{treated} \mathrm{by} \mathrm{acetampride} \mathrm{(toxicated} \mathrm{group).} \mathrm{The} \mathrm{results} \mathrm{of} \mathrm{the} \mathrm{effects} \mathrm{of}$ MO seeds extract on hematological parameters of intoxicated rats caused significant decreasments in total white blood cells counts (WBCs). While, MCV , MCH and MCHC were significantly unchanged relative to those of different from the control group but haemglobin $(\mathrm{Hb})$ and red blood cells (RBCs) was increased.

Histopathological studies confirmed chemical analysis results. Finally, from the obtained results and histopathological examination, it could be concluded that the administration of MO seeds dried extract of ethanolic oils might improve the liver and kidney functions in the present experimental rats.
\end{abstract}

\section{Key words:}

\section{Introduction}

Pesticides have become an important component of worldwide agriculture systems over the last decades, allowing for increase crop yields and food production in modern agriculture However, it has also significantly increasing in the concentration of pesticides in the food and environment, with associated public health hazard including hepato-nephrotoxicity.

Acetampride was a broad-spectrum nereistoxin analogue insecticide which widely produced and used for agricultural treatments in Egypt. This insecticide is an antagonist, acetampride as other pesticide is known to generate reactive oxygen species (ROS), Imamura et al (2010).

Natural antioxidants play a vital function against ROS for the defense system in animals and human body, as well as having roles in food industry and in chemoprevention of diseases. (Mohammed and Abd Manan 2015).
Seeds of Moringa oleifera L. (MOL) (horradish tree) are sources of vitamins (A, B, C, E, riboflavin, nicotinic acid, folic acid, pyridoxine, ascorbic acid, beta carotene), iron, calcium and alpha tocopherol. Also is a highly rich source of a specific antioxidant known as polyphenolics and flavonoids. Additionally, it's an important source of glucosinolate which is the precursor of the isothiocynate group of chemopreventives that can inhibit carcinogenesis. It contains the phytochemical niaziminin,which is found to have molecular components that can prevent the development of cancer, ( Purwal et al., 2010).

Moringa species are well-known for their antioxidant, anti-inflammatory, anticancer, and antihyperglycemic activities. Most of their biological activity is caused by their high content of alkaloids, saponins, glucosinolates, tannins, phenolic acids, and nitrile glycosides flavonoids, glucosides, and glucosinolates. (Abd Rani et al 2018).

Compaoré et al (2011) studied the nutrient composition and antioxidant properties of Moringa 
oleifera seeds. They found that Moringa oleifera seeds were particularly rich in proteins amounted $(35.37 \pm 0.07 \mathrm{~g} / 100 \mathrm{~g})$, lipids $(43.56 \pm 0.03 \mathrm{~g} / 100 \mathrm{~g})$, and minerals $\left(\mathrm{Mg}^{+2}\right.$ and $\left.\mathrm{zn}^{+2}\right)$. Glucose, fructose and sucrose were the main carbohydrates of Moringa oleifera seeds. Moringa oleifera seeds have the highest proanthocyanidin and flavonoids contents .

Ogbunugafor et al (2011) evaluated the oil extract of Moringa oleifera Lam (Moringaceae) seeds such as physico-chemical and antioxidant properties in comparism to palm oil. Moringa oleifera seeds gave oil, which showed yield of $41.47 \%$. Refractive index, melting point $\left({ }^{\circ} \mathrm{C}\right)$ and acid value $\left(\mathrm{mg} \mathrm{KOH} \mathrm{g}^{-1}\right)$ of $\mathrm{M}$. oleifera oil were $1.471 \pm 0.00,28 \pm 0.00{ }^{\circ} \mathrm{C}, 3.80 \pm 0.28$ respectivity Similarly, iodine $\left(\mathrm{I}_{2} 100 \mathrm{~g}^{-1}\right)$, saponification $\left(\mathrm{mg} \mathrm{KOHg}^{-1}\right)$ and peroxide $\left(\mathrm{mmol} \mathrm{kg}^{-1}\right)$ values obtained for

M.oleifera oil were $85.30 \pm 0.25,171.90 \pm 0.56$ and $8.10 \pm 0.07$. Total phenol (ug Gallic Acid Equivalent $\mathrm{g}^{-}$ ${ }^{1}$ ), total flavonoids (ug Rutin Equivalent $\mathrm{g}^{-1}$ ) and total antioxidant capacity (mg Ascorbic acid Equivalent $\mathrm{g}^{-1}$ ) were found to be $40.17 \pm 0.01,18.24 \pm 0.01,37.94 \pm 0.02$ respectively for M.oleifera oil which were $62.32 \pm 0.04$, $33.13 \pm 0.03,68.27 \pm 0.02$ for palm oil, respectively.

Mohammed and Abd Manan (2015) found that Moringa oleifera seeds extract contains total phenolics of $10.179 \pm 2.894(\mathrm{mg}$ Gallic acid equivalents / g dry matter) which was higher than the flavonoid (2.900 $\pm 0.0002 \mathrm{mg}$ Quercetin equivalents / $\mathrm{g}$ dry matter) and tannic acid of $(0.890 \pm 0.020 \mathrm{mg}$ Gallic acid equivalents / $g$ dry matter).

Toppo et al (2015) evaluated the hepatoprotective activity of Moringa oleifera against cadmium-induced toxicity in rats. They found a significant increasment in the activities of aspartate aminotransferase (AST), alanine transaminase (ALT), alkaline phosphatase (ALP), significant $(\mathrm{p} \leq 0.01)$ also increasment of lipid peroxidation (LPO) and a decrease in superoxide dismutase (SOD) activity and increasment in cadmium accumulation in liver for 28 days. Treatment with $M$. oleifera $500 \mathrm{mg} / \mathrm{kg}$ significantly $(\mathrm{p}<0.01)$ decreased the levels of ALP, AST and ALT activities and LPO and increase in SOD activity as compared to cadmium chloride induced group.

Ghafar et al (2017) found that M. oleifera seeds oil contained high yield of $36.84 \%$ for the seed using methanol as solvent ratio (1:10) after $5 \mathrm{~h}$ extraction. The highest percentages of total phenolic compound (TPC) were found to be 2027.07 (mg GAE/g of extract) after $3 \mathrm{~h}$ extraction. However, the total flavonoid compound (TFC) values in M. oleifera seeds were found to be 99.72 (mg QE/g of extract weight) after $5 \mathrm{~h}$ extraction.

Karaca et al (2019) studied the effect toxic of acetamiprid on liver and kidney in male rats after a 90 day subchronic exposure to $12.5,25$ and $35 \mathrm{mg} / \mathrm{kg}$. The biochemical and oxidative damage parameters were determined in the plasma and tissue samples as well as histopathological evaluation in the liver and kidney tissues. They found that acetamiprid caused oxidative damage and effected on the liver, denoted by injury markers including the levels of plasma cholesterol, ALT and AST enzymes. There was also a decreasment in plasma urea, uric acid and creatinine levels, all of which might result from liver injury.

Akinrinde et al (2020) investigated the protective effect of the dried methanol extract of Moringa oleifera (MO) in rats model of renal ischemia-reperfusion (IR) injury. They found that the extract of Moringa oleifera seeds significantly $(\mathrm{p}<0.05)$ ameliorated IR-induced increasement in malondialdehyde (MDA), protein carbonyls (PC) and advanced oxidation protein products (AOPP), and decreased serum blood urea nitrogen (BUN), and creatinine levels, and increased renal GPx and GST activities. Histopathology revealed marked improvement of tissue alterations induced by IR with both doses of Moringa oleifera .

\section{Materials and Methods}

Acetampride Purity $80 \%$ is a product of CrosAgro, Pesticides Company, Egypt , Moringa Oleifera L. seeds were obtained from in National Research Center (NRC). All other chemical from ElGomhoria company, and all Kits were supplied from Biodiagnostic company in Egypt .

Extraction of Moringa Oleifera L.: seeds were heat dried at $50{ }^{\circ} \mathrm{C}$ for 4 days. The seeds were pulverized using a blender to crush the seeds kernels thoroughly into fine powder. One $\mathrm{g}$ of $M$. oleifera crushed seeds was fed to a Soxhlet extractor fitted with a $250 \mathrm{~mL}$ roundbottom flask and a condenser. The extraction was run for $2 \mathrm{~h}$ in triplicate $(\mathrm{n}=3)$ with $100 \mathrm{~mL}$ of two different solvents: hexane and ethanol indvidually. The extracted oil yield was expressed as percentage in weight (mean \pm standard deviation). Oil yield extraction was higher for ethanol $(36.1 \% \pm 1.83 \%)$ than for hexane $(24.6 \% \pm$ $2.19 \%)$. (Vilaseca et al 2014)

\section{Determination chemical composition of Moringa oleifera L.seeds extract:}

Total phenol content (TPC) and total tannins in Moringa oleifera L. extract were determined by using Folin Ciocalteu's reagent . Total flavonoid content (TFC) of Moringa oleifera L. extract was determined by the aluminum chloride method using quercetin as a standard. Identification of Moringa Oleifera L. oil fatty acids according to Hartman and Lago (1973). The total antioxidant assays were carried out according to the report of Nabasree and Bratati (2007). Identification of phenolic compounds for Moringa oleifera L. seeds 
extract was carried out by HPLC according to Kim et al (2006).

Experimental animals: - Fifty adult male albino rats weighting $180-200 \mathrm{~g}$ were acquired from Cairo University's Department of Toxicology and Forensic Medicine's animal house. All animals were exposed to about 14 days of acclimatization. The animals were housed in isolated well-ventilated cages, under standard conditions (temperature $24-26^{\circ} \mathrm{C}$; humidity $60 \%$ and 12 light/12 dark cycles), with free access to standard diet and water according to guidelines from the Institutional Animal Care and Use Committee (IACUC).

Experimental design ,after the period of acclimatization, the animals were divided into five groups with ten animals per group, the main group (1) was utilized as a negative control. The second male group (2) was orally administered with acetamprid only $(30.85 \mathrm{mg} / \mathrm{kg})$, the third group (3) was given Moringa oleifera seeds dried extract of $200 \mathrm{mg} / \mathrm{kg} \mathrm{BW}$, the fourth group (4) was orally given combination of acetamprid and Moringa oleifera seeds dried extract, and fivth group (5) was given olive oil only, and elevated body weight every week. At the end of the experimental period 30 days, the blood samples were collected from eye vein under light ether anesthesia, allowed to clot, then centrifuged for $10 \mathrm{~min}$ at 3000 r.p.m. Serum was separated and stored at $\left(-20^{\circ} \mathrm{C}\right)$ to be utilized for the determination of liver and kidney functions. After the collection of blood samples, rats were sacrificed by cervical dislocation, and their livers and kidneys were immediately removed for subsequent investigations. The weights of some internal organs were determined.

Biochemical analyses:- Serum glucose level was determined by enzymatic calorimetrically according to the method of Trinder (1969). While , ALT and AST activites in serum were determined according to the method of Reitman and Frankel (1957). Enzymatic determination of urea was carried out according to the method of Fawcett and Scott (1960). Creatinine determination was carried out according to the method described by Schirmeister et al. (1964). Total protein was carried out according to the method of Gornall et al. (1949). Determination of total albumin was determined according to method oF Doumas et al. (1971). Triglycerides were determined colorimetrically according to the method of Fossati and Prencipe (1982). Total cholesterol was determined colorimetrically according to the method described by Richmond (1973).

Lipid peroxidation and antioxidant parameter measurements: Specimens from liver and kidney tissues from different treatment groups were separately weighed and homogenized in cold phosphate buffer $(\mathrm{pH}$ 7.4) using Teflon homogenizer. The homogenates were centrifuged at $14,000 \mathrm{rpm}$ for $20 \mathrm{~min}$ at $4{ }^{\circ} \mathrm{C}$. The supernatant was utilized to assess the malonaldehyde
(MDA) level (Okhawa et al. 1979), superoxide dismutase activity (Marklund and Marklund 1974), catalase activity (Aebi 1984), and reduced glutathione (GSH) concentration.

Histopathological examination was carried out by fixation of liver and kidney tissue organs in 10\% buffered formalin overnight and then embedded with paraffin. When analyzed was started, all paraffinembedded tissue was sectioned at $4 \mu \mathrm{m}$, deparaffinized in xylene, dehydrated by ethanol in decreasing concentrations of 100, 95 and $70 \%$ consecutively, and stained with haematoxyin and eosin. These specimens were examined under bright-field optical microscopy using a light microscope and 40X magnification powers. Corresponding digital images were captured and saved for later analysis (Banchroft et al ;1996).

Statistical Analysis :- The data were statistically analyzed using SPSS statistical package, (release 16) for windows. Data were expressed as mean \pm SE. Differences between two groups were analyzed by student $\mathrm{T}$ test. Multiple comparisons were performed by one-way ANOVA tests. (Gouda 2015)

\section{Results and Disscution}

\section{Bioactive components in Moringa oleifera seeds content :}

Moringa oleifera has been used as antidiabetic, antibacterial, and anti-inflammatory herbal drugs, its considered as a source of antioxidants, phenolic and flavonoids compounds. These bioactive compounds can exert antioxidant and anti-inflammatory effects that could induce cellular protection.

Total phenolic acids, total flavonoids and total tannin contents in Moringa oleifera seeds of dried ethanolic extract are determined and the results are recorded in Table (1):- from the obtained results the quantitative estimation of total phenolic acids content of the seeds dried ethanolic extract was found to be $44.25 \pm 1.13 \%$. Gallic acid was used as standard for total phenolic acid and tannin content. Phenolics have been found as strong antioxidants towards hindering the influence of free radicals and ROS, which is the basis of several chronic human infections. The presence of phenolic compound from M.oleifera seeds will encourage the utilization of the seeds for many purposes. (Mohammed and Manan 2015).

On other hand, the amount of the total flavonoids recorded in table (1) was found to be $114.36 \pm 0.72 \mu \mathrm{g} / \mathrm{g}$ dry matter. Quercetin equivalent $(\boldsymbol{\mu g}$ QE / g of dry matter) was used as standard for flavonoids.

Also, the total tannin content M. oleifera seeds is shown in (Table 1) and the percentage of total tannin 
content of the seeds was $20.77 \pm 1.10 \mu \mathrm{g} / \mathrm{g}$ dry matter . Tannins are natural polyphenols ubiquitously distributed in plants, such as vegetables, fruits and seeds. The quantity of these compounds are important in justifying the antioxidative properties of the seeds. (Mohammed and Manan 2015).

The phenolics and flavonoids are important indicators of antioxidant capacity of $M$. oleifera seeds. These compounds play vital function towards preventing diseases and sustain a state of well being. Quantitative estimation of phytoconstituent in the seed extract indicates that the plant seeds are rich in phenolics, flavonoids and tannins. The mentioned polyphenols are well known to have antioxidative power and effective scavenging of free radicals. The obtained results are in agrement with those reported by Mohammed and Manan (2015) and Ghafar et al (2017) .

Table 1. Total phenolic acid, flavonoid and tannin contents in Moringa oleifera L. seeds of dried ethanolic extract

\begin{tabular}{ll}
\hline Component & Percentage $(\%) \boldsymbol{\mu g} / \mathrm{g} \mathrm{DW}$ \\
\hline Total Phenolic acid & $44.25 \pm 1.13$ \\
Total Flavonoids & $114.36 \pm 0.72$ \\
Total tannins & $20.77 \pm 1.10$ \\
\hline
\end{tabular}

It has been reported that the MO seeds contain different classes of phytochemical compounds, vitamins, and carotenoids. Such these compounds contribute mainly to the antioxidant properties, as well as in other biological activities. $\beta$-carotene from $\mathrm{MO}$ seeds is converted efficiently into vitamin A in the body and has potential hepatoprotective effects . These reported studies have strongly suggested the importance of phenolic compounds from MO and their antioxidant properties. The main antioxidant activity associated with the phenolic contents is their ability to scavenge free radical formation. Such research evidences lead us to suggest that the observed improvement in the biochemical parameters in the acetampride toxicated rats in the present study was attributed to coadministration of the MO. The scavenging activities of MO can help to modulate the adverse effects of ROS resulted from acetamprid treatment. Extracts dried of MO seeds were extensively reported to possess a wide range of biological activities attributed to the role of $\mathrm{MO}$ as antioxidant agent .

Fatty acids composition of seeds extracted from Moringa olerifera:-

The fatty acids components of Moringa olerifera seeds are presented in Table(2). The values percentages of saturated fatty acids $(19.71 \%)$ were found to be palmitic acid $(10.32 \%)$, stearic acid $(8.57 \%)$ and myristic acid $(0.82 \%)$. while, the percentages of unsaturated fatty acids $(80.29 \%)$ were found to be oleic acid $(63.82 \%)$, linoleic acid (5.61\%), ó-linolenic acid (2.24\%) and arachidonic acid $(8.62 \%)$.

From the obtained results, it can be concluded that the major saturated fatty acids were found to be palmitic (C16:0) acids and stearic (C18:0) and the main unsaturated fatty acid was oleic acid (C18:1) with small amounts of linoleic acid (C18:2) $\alpha$-linolenic acid (C18:3) and archidonic acid ( C20:4)

The high percentage of oleic acid (monounsaturated fatty acid) in the oil makes it desirable in terms of nutrition and high stability cooking and frying oil (Abdulkarim et al., 2005; Anwar et al., 2006). A higher intake of oleic acid is associated with decreased risk of coronary heart disease caused by high cholesterol level in blood (Corbett, 2003). Moringa oleifera oil appears to be a potentially valuable and might be an acceptable substitute for high-oleic oils like olive and higholeic sunflower oils as our edible dietary fats and it also could be used for various commodities of commercial attributes (Anwar et al., 2005; Compaoré et al., 2011). The above mentioned results are in agreement with those reported by Ogbunugafor et al (2011) .

Table 2. Fatty acids composition of Moringa oleifera L.seeds extract

\begin{tabular}{lll}
\hline Fatty acid components & Common Name & Percentage (\%) \\
\hline $\mathrm{C}_{14: 0}$ & Myristic acid & 0.82 \\
$\mathrm{C}_{16: 0}$ & Palmitic acid & 10.32 \\
$\mathrm{C}_{18: 0}$ & Stearic acid & 8.57 \\
$\mathrm{C}_{18: 1}$ & Oleic acid & 63.82 \\
$\mathrm{C}_{18: 2}$ & Linoleic acid & 5.61 \\
$\mathrm{C}_{18: 3}$ & $\alpha$-Linolenic acid & 2.24 \\
$\mathrm{C}_{20: 4}$ & Archidonic acid & 8.62 \\
Total saturated fatty acid \% & 19.71 & \\
Total unsaturated fatty acid\% & 80.29 & \\
\hline
\end{tabular}


Determination of oxidative capacity of seeds:

Total antioxidant capacity of Moringa oleifera seeds dried extract under different solvent concentrations were determined which compared with vit. $\mathrm{C}$ as control . The obtained results are presented in Table (3). From these results, it could be concluded that the amounts of antioxidant capacity of ethanol extract were found to be $143.29 \pm 0.37, \quad 178.10 \pm 2.18, \quad 189.18 \pm 2.06 \quad$ and $222.47 \pm 0.81$ at $50,100,150$ and $200 \mathrm{ug} / \mathrm{ml}$ respectively. On the other hand, these values with hexane extracted were found to be $110.69 \pm 3.43$,
$117.25 \pm 0.26,128.98 \pm 1.51$ and $149.58 \pm 1.71$ at same concentrations. While, the total antioxidant capacity with vit. C were found to be $127.97 \pm 5.15,147.37 \pm 7.01$, $230.16 \pm 3.58$ and $243.46 \pm 2.06$ at same concentrations respectively.

The obtained data showed that the ethanolic Moringa oleifera dried seeds extract was found as antioxidant value more than hexane extract and increased by increased concentrations. These results are more higher than those reported by Compaoré et al( 2011) .

Table 3. Total antioxidant capacity of Moringa oleifera L. seeds extract by different solvents :-

\begin{tabular}{ccccc}
\hline Solvents & \multicolumn{5}{c}{ Concentrations $\boldsymbol{\mu g} / \mathbf{m l}$} \\
\cline { 2 - 5 } & 50 & \multicolumn{4}{c}{100} & \multicolumn{4}{c}{150} \\
\cline { 2 - 5 } & \multicolumn{4}{c}{ Antioxidant capacity } \\
\hline Ethanol & $143.29 \pm 0.37$ & $178.10 \pm 2.18$ & $189.18 \pm 2.06$ & $222.47 \pm 0.81$ \\
Hexane & $110.69 \pm 3.43$ & $117.25 \pm 0.26$ & $128.98 \pm 1.51$ & $149.58 \pm 1.71$ \\
Vit.C(control) & $127.97 \pm 5.15$ & $147.37 \pm 7.01$ & $230.16 \pm 3.58$ & $243.46 \pm 2.06$ \\
\hline
\end{tabular}

Effect of ethanolic Moringa oleifera seeds extracted on organs' weights of the experimental rats after 30 days:-

The weights of some internal organs of the experimental rats are presented in Table (4). From those results, there were no significant differences between these results of control group of , MO, acetamprid, olive oil and acetamprid treated with Moringa oleifera had about the same weights of the studied organs (e.g. kidney, heart, spleen and lung). compared with those of control group (G1), the weights of the liver recorded (6.5) significant differences $(p<0.05)$ than that of the intoxicated acetampride group (9.5). Also no difference was observed between control and acetamprid treated with moringa (G4) groups.

The same trend also observed in brain of control (G1)which recorded $1.59 \pm 0.05 \mathrm{~g}$ significant differences $(\mathrm{p}<0.05)$ than those for the intoxicated acaetamprid rats (G2) which recorded $7.56 \pm 0.06 \mathrm{~g}$. and no differences between control (G1) and acetamprid treated with moringa (G4). The weights of the testes recorded in control (G1) of $3.05 \pm 0.099 \mathrm{~g}$ which had significant differences $(p<0.05)$ than those of the intoxicated acetamprid(G2)which recorded $3.65 \pm 0.149 \mathrm{~g}$. and no difference was observed between group of control and acetamprid treated with moringa(G4). On the other hand the weights of the kidneys in the acetamprid intoxicated rats were showed significantly $(p<0.01)$ lower than those of control group. Similar trend was obtained for the heart, spleen and lung. Weight of control brain recorded $1.59 \mathrm{~g}$, which were significantly lower $(\mathrm{p}<0.01)$ than those of the acetamprid intoxicated group. In general, coadministration of MO decreased these differences.

Table (4): Effect of dried ethanolic Moringa oleifera seeds extract on organs' weights (g) of the experimental rats after 30 days:-

\begin{tabular}{llllllll}
\hline group & liver & kidneys & lungs & heart & brain & spleen & testes \\
\hline G1 & $6.5 \pm 0.46$ & $2.26 \pm 0.11$ & $1.8 \pm 0.11$ & $0.95 \pm 0.03$ & $1.59 \pm 0.05$ & $1.05 \pm 0.064$ & $3.05 \pm 0.099$ \\
G2 & $9.5 \pm 0.38$ & $2.054 \pm 0.11$ & $1.41 \pm 0.09$ & $0.84 \pm 0.04$ & $1.56 \pm 0.06$ & $0.71 \pm 0.057$ & $3.65 \pm 0.149$ \\
G3 & $6.64 \pm 0.41$ & $2.042 \pm 0.17$ & $1.6 \pm 0.12$ & 0.8780 .05 & $1.548 \pm 0.10$ & $0.62 \pm 0.059$ & $2.66 \pm 0.232$ \\
G4 & $7.38 \pm 0.24$ & $1.91 \pm 0.07$ & $1.39 \pm 0.11$ & $0.88 \pm 0.02$ & $1.59 \pm 0.05$ & $1.05 \pm 0.038$ & $3.21 \pm 0.116$ \\
G5 & $7.8 \pm 0.42$ & $2.21 \pm 0.11$ & $1.75 \pm 0.22$ & $0.94 \pm 0.04$ & $1.63 \pm 0.06$ & $0.74 \pm 0.099$ & $3.55 \pm 0.207$ \\
\hline
\end{tabular}

Effect of dried ethanolic Moringa oleifera seeds extract on kidneys and liver functions of the experimental rats after 30 days:-

Activites of the serum of AST , ALT , albumin, total protein which represent the functional status of the liver, and also urea and creatinine level which indicatives of the kidneys function are represented in table (5 and 6).

The effects of M. oleifera seeds extract on the markers of renal injury and function of experimental rats were studied and the obtained results are tabulated in table (5). These results it has been observed that acetamprid intoxicated group caused significantly ( $p$ 
$<0.05)$ increaments in the serum levels of urea when compared with the controls (Akinrinde et al 2020). but no significant change in creatinine were observed inti intoxicated group showed. However, M. oleifera at the dose of $200 \mathrm{mg} / \mathrm{kg}$ b.w (G3) caused significantly $(\mathrm{P}<0.05)$ reduction in serum urea and creatinine levels of compared to the acetamprid intoxicated $\operatorname{group}(\mathrm{G} 2)$. On the other hand, there was no significant change in serum urea and creatinine levels of olive oil group (G5) when compard with M. oleifera (G3)at dose of 200 $\mathrm{mg} / \mathrm{kg}$ b.w. .These results are similar to those obtained by Fakurazi et al (2012), and Al-Malki and El Rabey (2015).

The activity of serum ALT and AST used as biochemical markers for evaluation of early hepatic injury. The values of ALT and AST activities as well as albumin and total protein content of the experimental rats induced dried ethanolic $M$. olifera seeds extract are measured and the obtained data are recorded in Table(6). From the obtained results, the above values were significantly increased in the intoxicated acetamprid group $(\mathrm{G} 2)$ when compared with control group (G1). On the other hand, treated group (G3) of M. oleifra at dose $200 \mathrm{mg} / \mathrm{kg}$ b.w. were significantly decreased the values compared with control group (G1) and olive oil ( G5). These data are in greement with those reported by Karaca et al (2019). From the above data it could concluded that in groups that were treated with dried extract improved liver function relative to the activity of liver marker enzymes were significantly ( $\mathrm{p}<0.05$ ) improved also results showed decreases in serum albumin and total protein levels in group treated by moringa oleifera seeds extract if compared with the control group $(\mathrm{G} 1)$.

Table 5. Effect of dried ethanolic Moringa oleifera seeds extract on kidneys and liver functions of experimental rats after 30 days:-

\begin{tabular}{|c|c|c|c|c|c|}
\hline Biomarkers & $\begin{array}{c}\text { Control } \\
1 \mathrm{ml} \mathrm{Dw} / \mathrm{kg} \text { b.w } \\
\mathrm{G} 1\end{array}$ & $\begin{array}{c}\text { pesticide. } \\
\text { 30.85mg/kg b } \\
\text {.w } \\
\text { G2 }\end{array}$ & $\begin{array}{c}\text { Moringa } \\
\text { oleifera } \\
\text { 200mg/kg b.w } \\
\text { G3 }\end{array}$ & $\begin{array}{c}\text { Pesticide. } \\
\text { \& Moringa oleifera } \\
\text { 30.85mg/kg b.w } \\
\text { \&200mg/kg b.w } \\
\text { G4 }\end{array}$ & $\begin{array}{c}\text { Olive oil } \\
\text { G5 }\end{array}$ \\
\hline Urea (mg/dl) & $41.800 \pm 2.557$ & $49.600 \pm 1.965$ & $43.800 \pm 2.634$ & $38.800 \pm 0.860$ & $43.200 \pm 2.818$ \\
\hline $\begin{array}{l}\text { Creatinine } \\
(\mathrm{mg} / \mathrm{dl})\end{array}$ & $0.680 \pm 0.0374$ & $0.540 \pm 0.0245$ & $0.580 \pm 0.0583$ & $0.520 \pm 0.0583$ & $0.560 \pm 0.0245$ \\
\hline ALT (U/I) & $35.000 \pm 3.406$ & $54.000 \pm 6.229$ & $37.600 \pm 2.619$ & $35.400 \pm 3.530$ & $48.000 \pm 0.775$ \\
\hline AST (U/I) & $90.200 \pm 5.324$ & $107.400 \pm 7.040$ & $79.000 \pm 3.479$ & $78.200 \pm 1.463$ & $95.800 \pm 3.891$ \\
\hline Albumin (g/dl) & $3.366 \pm 0.114$ & $4.280 \pm 0.111$ & $3.780 \pm 0.171$ & $3.120 \pm 0.180$ & $3.720 \pm 0.0735$ \\
\hline $\begin{array}{c}\text { Total } \\
\text { protein }(g / d l)\end{array}$ & $6.420 \pm 0.250$ & $6.900 \pm 0.263$ & $6.500 \pm 0.270$ & $5.780 \pm 0.111$ & $5.400 \pm 0.173$ \\
\hline
\end{tabular}

Effect of dried ethanolic Moringa oleifera seeds extract on serum cholesterol and triglyceride of expermintal rats after 30 days: -

Effect of dried ethanolic Moringa oleifera seeds extract on serum total cholesterol and triglyceride of expermintal rats after 30 days were evaluated and the results are presented in Table (6). From the obtained results, there were significant declines in total cholesterol (TC) and triglyceride (TG) levels of the treated group with dried ethanolic $M$. oleifera seeds extract at dose of $200 \mathrm{mg} / \mathrm{kg}$ b.w. if compared with intoxicated acetamprid group (G2), and no significant differences was found in olive oil group (G5). These results are about similar to these results reported by Toppo et al (2015).
Effect of dried ethanolic Moringa oleifera seeds extract on blood glucose of expermintal rats after 30 days:-

Table (6) showed the effect of dried ethanolic $M$. oleifera seeds extract treatment on serum glucose level s of experimental rats. From these data, it can be seen that the serum glucose content of intoxicated acetampride group (G2) was found to be 114.2 \pm 2.267 $\mathrm{mg} / \mathrm{dl}$ which higher than that of the other groups after the experimental period (4 weeks) which significantly was decreased compared with the value of control. These results are similar to those reported by Al-Malki and El Rabey( 2015). 
Table 6. Effect of dried ethanolic Moringa oleifera seeds extract on blood glucose, cholesterol and triglyceride of expermintal rats after 30days:-

\begin{tabular}{|c|c|c|c|c|c|}
\hline Biomarkers & $\begin{array}{c}\text { Control } \\
\mathbf{1 ~ m l ~ D w / k g ~ b . w ~} \\
\text { G1 }\end{array}$ & $\begin{array}{c}\text { pesticide. } \\
\text { 30.85mg/kg b } \\
\text {.w } \\
\text { G2 }\end{array}$ & $\begin{array}{c}\text { Moringa } \\
\text { oleifera } \\
\text { 200mg/kg b.w } \\
\text { G3 }\end{array}$ & $\begin{array}{c}\text { Pesticide. } \\
\text { \& Moringa } \\
\text { oleifera } \\
\text { 30.85mg/kg b.w } \\
\text { \&200mg/kg b.w } \\
\text { G4 } \\
\end{array}$ & $\begin{array}{l}\text { Olive oil } \\
\text { G5 }\end{array}$ \\
\hline $\begin{array}{c}\text { Cholesterol } \\
(\mathrm{mg} / \mathrm{dl})\end{array}$ & $128.800 \pm 4.443$ & $204.800 \pm 4.067$ & $144.400 \pm 2.731$ & $176.000 \pm 4.301$ & $143.200 \pm 3.216$ \\
\hline $\begin{array}{c}\text { Triglyceride } \\
\text { (mg/dl) }\end{array}$ & $68.000 \pm 4.506$ & $106.400 \pm 3.763$ & $71.400 \pm 5.921$ & $67.200 \pm 4.420$ & $63.800 \pm 2.634$ \\
\hline $\begin{array}{l}\text { Glucose } \\
\text { (mg/dl ) }\end{array}$ & $121.000 \pm 2.898$ & $114.200 \pm 2.267$ & $98.400 \pm 5.784$ & $113.800 \pm 4.140$ & $115.600 \pm 9.255$ \\
\hline
\end{tabular}

However, these observations may be revalued to that Moringa oleifera seeds dried extract reduced serum AST, ALT, albumin and total protein levels ,Hypoglycemic and hypolipidemic activity in the bioassay could be a result of phytochemicals effect which are bioactive antioxidant substances that have been associated with a protective effect against chronic degenerative diseases Olayaki et al., (2015) .

Effects of dried ethanolic Moringa oleifera seeds extract on haematological parameters of experimental rats after 30 days :
The results of the effect of $M$. oleifera seeds dried extract on haematological parameters are presented in Table (7). The dried extract of seeds caused significant decreases $(\mathrm{P}<0.05)$ in total white blood cell counts. Significant decrease was also observed in the neutrophil counts of rats. Decreases found in $\mathrm{MCV}$, $\mathrm{MCH}$. and $\mathrm{MCHC}$ but were not significantly different at those of control group and increases in the haemglobin level and RBCs count were observed under the present conditions .

Table 7. Effects of ethanolic moringa oleifera seeds extract on haematological parameters of experimental rats after 30 days :

\begin{tabular}{|c|c|c|c|c|c|}
\hline Biomarkers & $\begin{array}{c}\text { Control } \\
1 \mathrm{ml} \mathrm{Dw/kg} \mathrm{b.w} \\
\text { G1 }\end{array}$ & $\begin{array}{c}\text { pesticide. } \\
\text { 30.85mg/kg b } \\
\text {.w } \\
\text { G2 }\end{array}$ & $\begin{array}{c}\text { Moringa } \\
\text { oleifera } \\
\text { 200mg/kg b.w } \\
\text { G3 }\end{array}$ & $\begin{array}{c}\text { Pesticide. } \\
\text { \& Moringa } \\
\text { oleifera } \\
\text { 30.85mg/kg b.w } \\
\text { \&200mg/kg b.w } \\
\text { G4 } \\
\end{array}$ & $\begin{array}{l}\text { Olive oil } \\
\text { G5 }\end{array}$ \\
\hline $\begin{array}{c}\text { Hemoglobin } \\
(\mathrm{g} / \mathrm{dl})\end{array}$ & $11.160 \pm 0.364$ & $12.0 \pm 0.245$ & $12.860 \pm 0.424$ & $12.920 \pm 0.260$ & $11.000 \pm 0.904$ \\
\hline $\begin{array}{c}\text { RBCs } \\
\text { million/cmm }\end{array}$ & $5.100 \pm 0.167$ & $3.920 \pm 0.097$ & $4.320 \pm 0.159$ & $4.820 \pm 0.150$ & $3.720 \pm 0.309$ \\
\hline MCV fl & $107.600 \pm 4.654$ & $122.200 \pm 2.973$ & $113.000 \pm 3.302$ & $105.200 \pm 1.020$ & $118.000 \pm 2.950$ \\
\hline MCH pg & $26.600 \pm 1.568$ & $30.800 \pm 0.374$ & $30.000 \pm 0.548$ & $27.000 \pm 0.837$ & $29.400 \pm 0.927$ \\
\hline MCHC g/dl & $24.600 \pm 0.678$ & $25.000 \pm 0.447$ & $26.600 \pm 0.600$ & $25.400 \pm 0.678$ & $25.200 \pm 0.917$ \\
\hline $\begin{array}{c}\text { WBCs } \\
\text { thousand/cmm }\end{array}$ & $8.300 \pm 1.020$ & $8.900 \pm 1.100$ & $7.500 \pm 0.600$ & $8.400 \pm 0.340$ & $9.700 \pm 1.140$ \\
\hline Segmented \% & $19.000 \pm 1.789$ & $32.200 \pm 3.441$ & $20.800 \pm 7.123$ & $20.000 \pm 0.632$ & $34.400 \pm 2.379$ \\
\hline Lymphocyte\% & $72.600 \pm 1.778$ & $60.600 \pm 3.341$ & $74.400 \pm 3.709$ & $72.400 \pm 1.030$ & $58.000 \pm 2.608$ \\
\hline Staff \% & $1.000 \pm 0.632$ & $1.000 \pm 0.447$ & $0.447 \pm 0.583$ & $2.000 \pm 0.632$ & $2.000 \pm 0.837$ \\
\hline Monocyte \% & $5.600 \pm 0.927$ & $3.600 \pm 0.812$ & $3.600 \pm 0.510$ & $3.800 \pm 0.374$ & $4.000 \pm 0.447$ \\
\hline Eosinophil\% & $2.800 \pm 1.068$ & $2.200 \pm 0.970$ & $1.400 \pm 0.980$ & $1.800 \pm 0.374$ & $1.600 \pm 1.166$ \\
\hline Basophils\% & $0.040 \pm 0.240$ & $0.030 \pm 0.200$ & $0.040 \pm 0.100$ & $0.020 \pm 0.200$ & $0.040 \pm 0.210$ \\
\hline
\end{tabular}




\section{Histopathological finding:}

- Group (G1)of rats kept as control :

Liver :-There was no histopathological alteration and the normal histological structure of the central vein and surrounding hepatocytes in the parenchyma were recorded in Fig.1

Kidney :There was no histopathological alteration and the normal histological structure of the glomeruli and tubules at the cortex were recorded in Fig.6.

- Group (G2) of rats induced(intoxicated) with acetampride :

Liver :Fatty change and coagulative necrosis were observed in the hepatocytes surrounding and adjacent the dilated central vein (Fig.2), associated with focal inflammatory cells aggregation in the hepatic parenchyma .The portal area showed congestion in the portal vein associated with few inflammatory cells infiltration mainly surrounding the hyperplastic and newly formed bile ducts bile ducts .

Kidney_ : Severe congestion was noticed in the cortical blood vessels associated with degeneration and desquamation in the tubular lining epithelium at the cortex (Fig.7).

- $\operatorname{Group}(\mathrm{G} 3)$ of rats treated with the dried extract :

Liver :There was no histopathological alteration as recorded in Fig.3.
kidney_There was no histopathological alteration as recorded in Fig.8.

- Group(G4) of rats protected by the dried extract then treated with acetampride

Liver :Dilatation was observed in the central vein while the portal area showed few inflammatory cells infiltration (Fig.4)

Kidney_There was no histopathological alteration as recorded in Fig.9.

The hepatic and renal histopathological found that rats induced (intoxicated) with acetampride had shown the hepatocytes surrounding and adjacent the dilated central vein, associated with focal inflammatory cells aggregation in the hepatic parenchyma. The portal area showed congestion in the portal vein associated with few inflammatory cells infiltration mainly surrounding the hyperplastic and newly formed bile ducts bile ducts and sever congestion was noticed in the cortical blood vessels associated with degeneration and desquamation in the tubular lining epithelium at the cortex in kidney, that improved after treatment with MO, due to the ability of MO dried extract to reduce the oxidative stress induced by toxicants.

- Group (G5) of rats administrated the olive oil :

Liver :There was no histopathological alteration as recorded in Fig.5.

Kidney :There was no histopathological alteration as recorded in Fig.10.

\section{Liver histopathlogy}

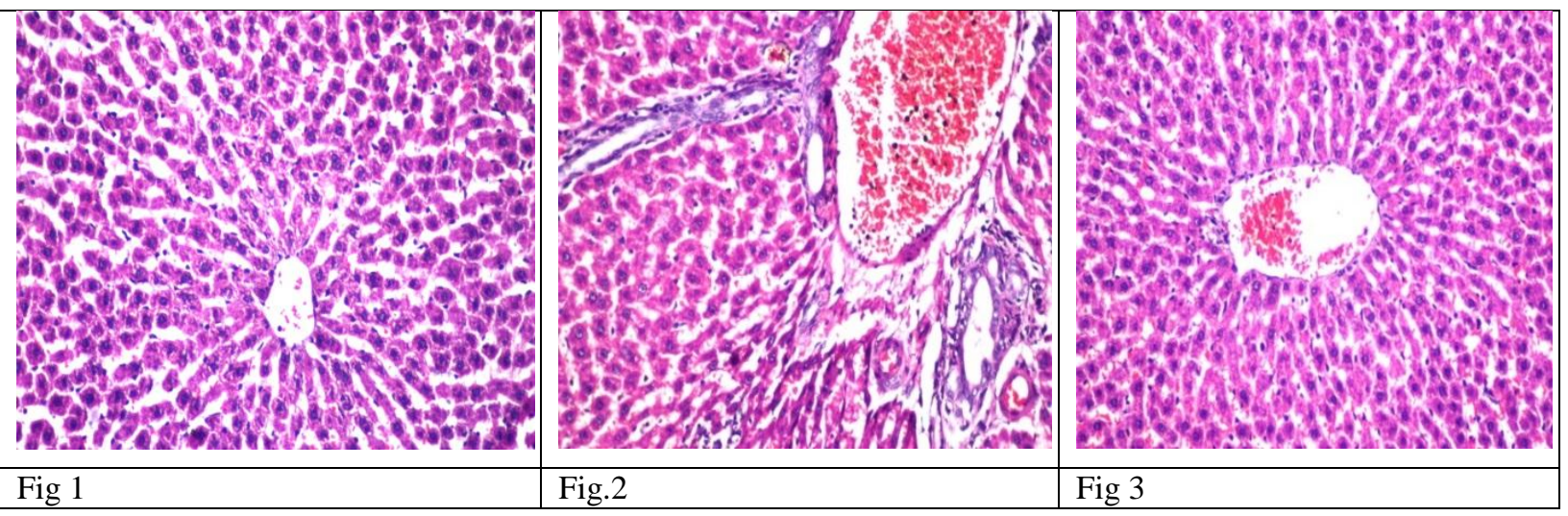




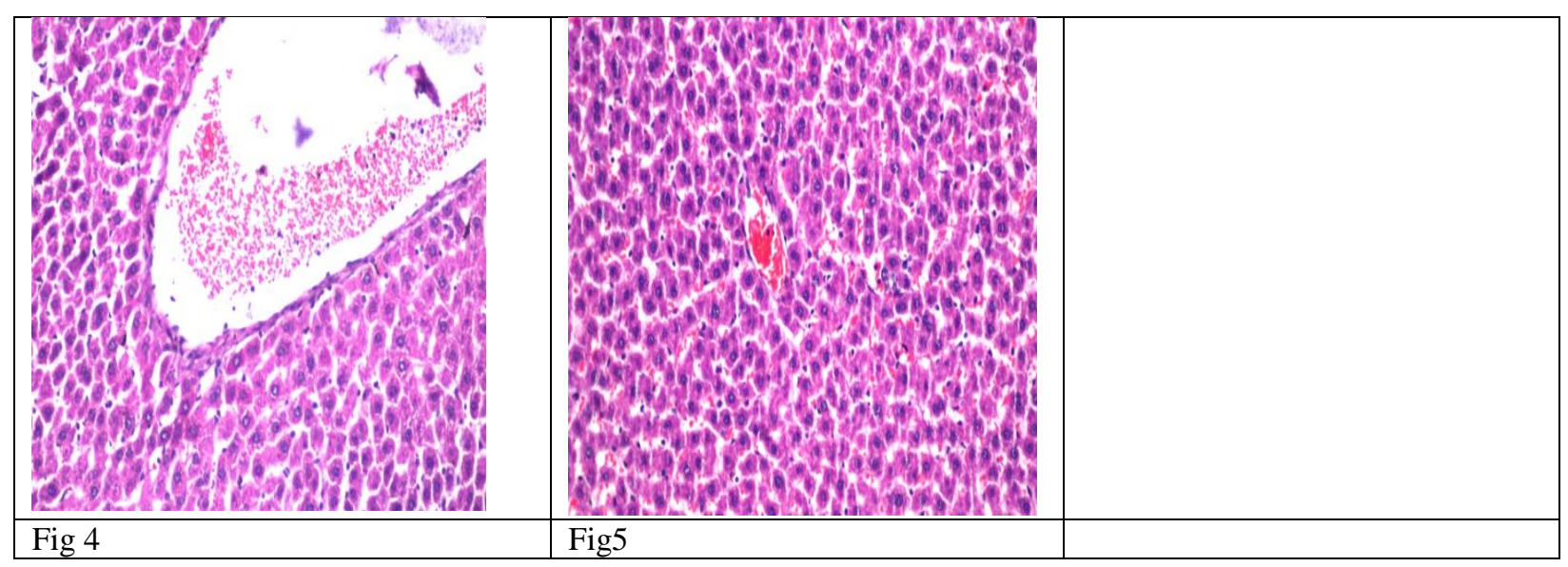

Kidney histopathology

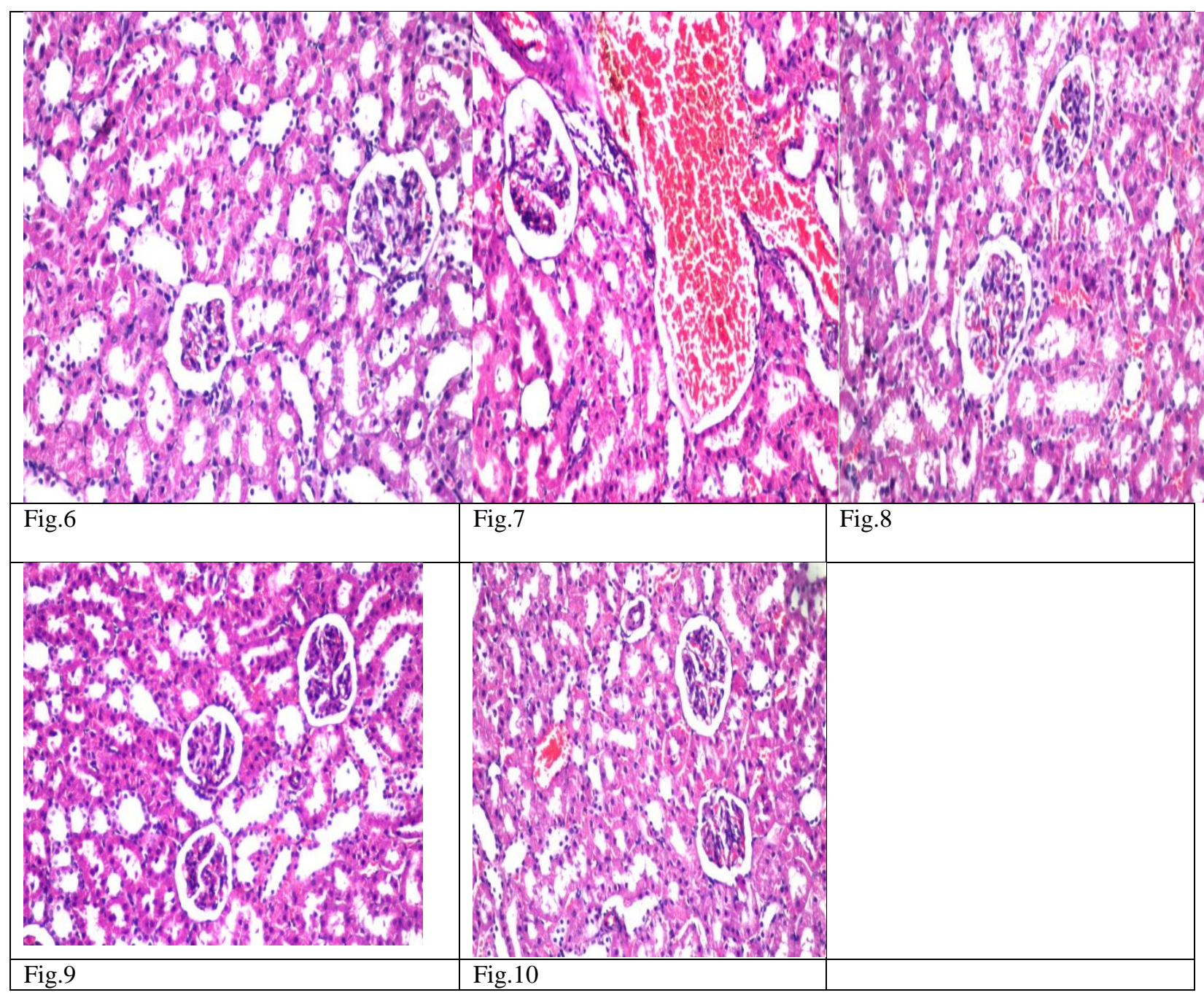




\section{Conclusion}

From the above mentioned results, it could be concluded that the Moringa oleifera, is one of the important medicinal plants which is one of the most widely cultivated species of the family Moringaceae. Various parts of the plant have been used for human medication. Phytochemically, it is known as rich source of glycosides, phenols, sterols, flavanol glycosides that Moringa oleifera might be medicinally important and/or nutritionally valuable. $M$. oleifera seeds dried extract possess antioxidant and free radical scavenging property, which could be helpful in reducing the oxidative stress caused by acetamprid toxicity by reducing the ROS production, maintaining the antioxidant potential, and significantly reducing elevated serum biomarker levels in the body. The present study showed that supplementation of $M$. oleifera extract ( $200 \mathrm{mg} / \mathrm{kg}$ ) improved hepatoprotective effect against actampride harmful.

\section{Reference}

Abd Rani, N. Z., Husain, K., \& Kumolosasi, E. (2018). Moringa genus: a review of phytochemistry and pharmacology. Frontiers in Pharmaco., 9:108.

Abdulkarim, S. M., Long, K., Lai, O. M., Muhammad, S. K. S., \& Ghazali, H. M. (2005). Some physico-chemical properties of Moringa oleifera seed oil extracted using solvent and aqueous enzymatic methods. Food chemistry, 93(2):253-263.

Aebi, H. (1984). Catalase in vitro. Methods in enzymology, 105:121-126.

Akinrinde, A. S., Oduwole, O., Akinrinmade, F. J., \& Bolaji-Alabi, F. B. (2020). Nephroprotective effect of methanol extract of Moringa oleifera leaves on acute kidney injury induced by ischemia-reperfusion in rats. African Health Sciences, 20(3):1382-1396.

Al-Malki, A. L., \& El Rabey, H. A. (2015). The antidiabetic effect of low doses of Moringa oleifera Lam. seeds on streptozotocin induced diabetes and diabetic nephropathy in male rats. BioMed Research International,

Anwar, F., Ashraf, M., \& Bhanger, M. I. (2005). Interprovenance variation in the composition of Moringa oleifera oilseeds from Pakistan. Journal of the American Oil Chemists' Society, 82(1): 45-51.

Anwar, F., Zafar, S. N., \& Rashid, U. (2006). Characterization of Moringa oleifera seed oil from drought and irrigated regions of Punjab, Pakistan. Grasas Y Aceites, 57(2): 160-168.

Banchroft, J. D., Stevens, A., \& Turner, D. R. (1996). Theory and practice of histological techniques Fourth Ed Churchil Livingstone. New York, London, San Francisco, Tokyo:[Google Scholar].

Compaoré, W. R., Nikièma, P. A., Bassolé, H. I. N., Savadogo, A., \& Mouecoucou, J. (2011). Chemical composition and antioxidative properties of seeds of Moringa oleifera and pulps of Parkia biglobosa and Adansonia digitata commonly used in food fortification in Burkina Faso. Current Research Journal of Biological Sciences, 3(1): 64-72.

Corbett, P. (2003). Opportunities for high-oleic vegetables oils. INFORM-CHAMPAIGN-, 14(8): 480-481.

Doumas, B. T., Watson, W. A., \& Biggs, H. G. (1971). Albumin standards and the measurement of serum albumin with bromcresol green. Clinica chimica acta, 31(1), 87-96.

Fakurazi, S., Sharifudin, S. A., \& Arulselvan, P. (2012). Moringa oleifera hydroethanolic extracts effectively alleviate acetaminophen-induced hepatotoxicity in experimental rats through their antioxidant nature. Molecules, 17(7), 8334-8350.

Fawcett, J., \& Scott, J. (1960). A rapid and precise method for the determination of urea. Journal of Clinical Pathology, 13(2):156-159.

Fossati, P., \& Prencipe, L. (1982). Serum triglycerides determined colorimetrically with an enzyme that produces hydrogen peroxide. Clinical Chemistry, 28(10):2077-2080.

Ghafar, F., Nazrin, T. T. N. N., Salleh, M. M. R., Hadi, N. N., Ahmad, N., Hamzah, A. A., ... \& Azman, I. N. (2017). Total phenolic content and total flavonoid content in moringa oleifera seed. Galeri Warisan Sains, 1(1): 23-25.

Gornall, A. G., Bardawill, C. J., \& David, M. M. (1949). Determination of serum proteins by means of the biuret reaction. Journal of biological chemistry, 177(2), 751-766.

Gouda, M. A. (2015). Common pitfalls in reporting the use of SPSS software. Medical Principles and Practice, 24(3): 300.

Hartman, L., \& Lago, R. C. (1973). Further observations concerning effects of unsaponifiable constituents on the properties of coffee seed oil. Journal of the American Oil Chemists' Society, 50(3): 99-100.

Imamura, T., Yanagawa, Y., Nishikawa, K., Matsumoto, N., \& Sakamoto, T. (2010). Two cases of acute poisoning with acetamiprid in humans. Clinical Toxicology, 48(8): 851-853.

Karaca, B. U., Arican, Y. E., Boran, T., Binay, S., Okyar, A., Kaptan, E., \& Özhan, G. (2019). Toxic effects of subchronic oral acetamiprid exposure in rats. Toxicology and Industrial Health, 35(11-12): 679-687.

Kim, J. W., \& Mazza, G. (2006). Optimization of extraction of phenolic compounds from flax shives by pressurized low-polarity water. Journal of Agricultural and Food Chemistry, 54(20): 75757584. 
Marklund, S., \& Marklund, G. (1974). Involvement of the superoxide anion radical in the autoxidation of pyrogallol and a convenient assay for superoxide dismutase. European Journal of Biochemistry, 47(3): 469-474.

Mohammed, S., \& Abd Manan, F. A. (2015). Analysis of total phenolics, tannins and flavonoids from Moringa oleifera seed extract. Journal of Chemical and Pharmaceutical Research, 7(1): 132135.

Nabasree, D., \& Bratati, D. (2007). Antioxidant activity of Azadirachta indica A. Juss.(neem) leaf. Phytochemistry and Pharmacology III: 449457.

Ogbunugafor, H. A., Eneh, F. U., Ozumba, A. N., Igwo-Ezikpe, M. N., Okpuzor, J., Igwilo, I. O., ... \& Onyekwelu, O. A. (2011). Physico-chemical and antioxidant properties of Moringa oleifera seed oil. Pakistan Journal of Nutrition, 10(5), 409-414.

Okhawa, H., Ohishi, N., \& Yogi, K. (1979). Assay for lipid peroxidation in animal tissue by TBA reaction. Analitical Biochemistry, 95: 35-38.

Olayaki, L. A., Irekpita, J. E., Yakubu, M. T., \& Ojo, O. O. (2015). Methanolic extract of Moringa oleifera leaves improves glucose tolerance, glycogen synthesis and lipid metabolism in alloxaninduced diabetic rats. Journal of Basic and Clinical Physiology and Pharmacology, 26(6): 585-593.

Purwal, L., Pathak, A. K., \& Jain, U. K. (2010). In vivo anticancer activity of the leaves and fruits of
Moringa oleifera on mouse melanoma. Pharmacologyonline, 1:655-665.

Reitman, S., \& Frankel, S. (1957). A colorimetric method for the determination of serum glutamic oxalacetic and glutamic pyruvic transaminases. American Journal of Clinical Pathology, 28(1):56-63.

Richmond, W. (1973). Preparation and properties of a cholesterol oxidase from Nocardia $\mathrm{sp}$. and its application to the enzymatic assay of total cholesterol in serum. Clinical Chemistry, 19(12):1350-1356.

Schirmeister, J., Willmann, H., \& Kiefer, H. (1964). Plasmakreatinin als grober Indikator der Nierenfunktion. DMW-Deutsche Medizinische Wochenschrift, 89(21):1018-1023.

Toppo, R., Roy, B. K., Gora, R. H., Baxla, S. L., \& Kumar, P. (2015). Hepatoprotective activity of Moringa oleifera against cadmium toxicity in rats. Veterinary World, 8(4), 537.-540

Trinder, P. (1969). Determination of glucose in blood using glucose oxidase with an alternative oxygen acceptor. Annals of Clinical Biochemistry, 6(1): 2427.

Vilaseca, M., López-Grimau, V., \& GutiérrezBouzán, C. (2014). Valorization of waste obtained from oil extraction in Moringa oleifera seeds: coagulation of reactive dyes in textile effluents. Materials, 7(9):6569-6584. 


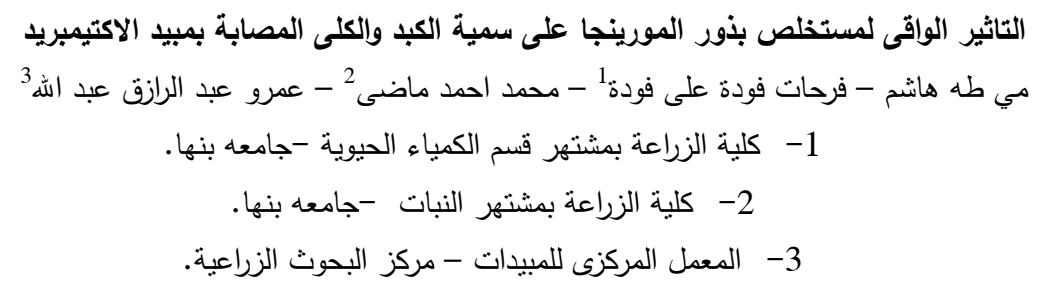

تهدف الدراسة الى القاء الضوء على التأثير الواقى لمستخلص كحولى الايثانى الجاف لبذور المورينجا على سمية كل من انسجة وانزيمات

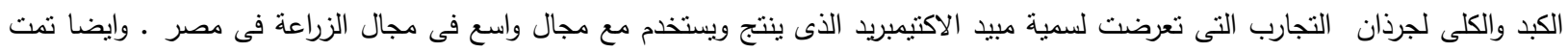

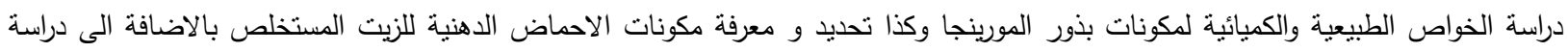

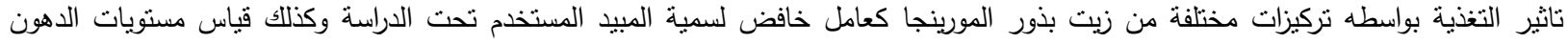

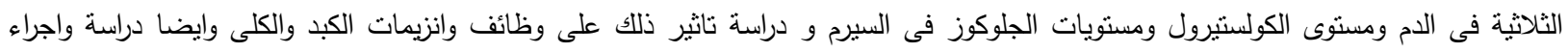

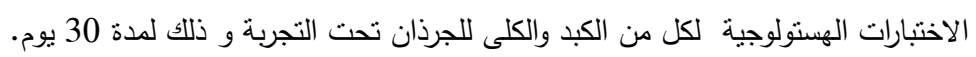

اوضحت الننائج المتحصل عليها ان نسبة الككونات الكميائية الحيوية للفينولات الكلية والفلافينويدات والتانين فى المستخلص الايثانولى ولى

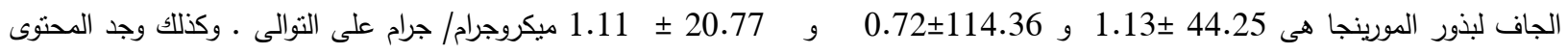

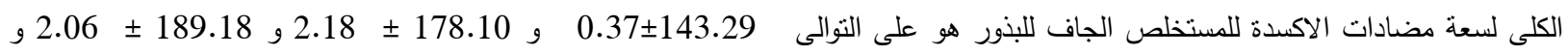

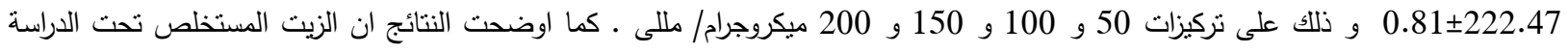

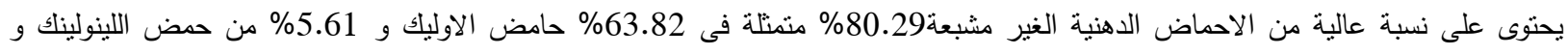
2.24\% حامض الفا -لينولينك و 82. 82\% من حامض الاراشيدونيك بينما نسبة الاحماض الدهنية المشبعه 19.71\% المتمثلة فى حامض البالمتيك التى كانت نسبتة 10.32\% و الاستياريك 8.57\% بينما الميرستيك

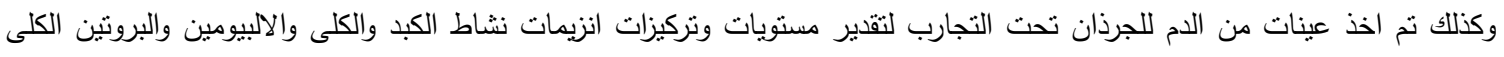

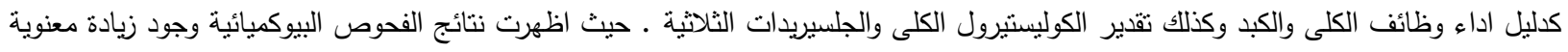

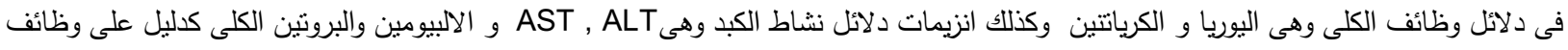

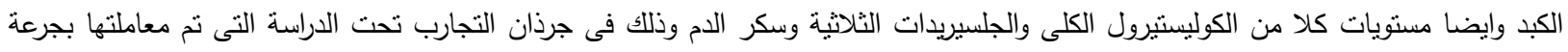

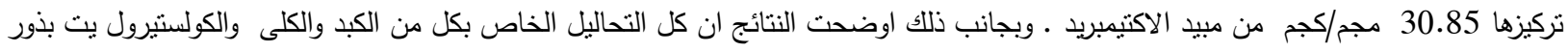

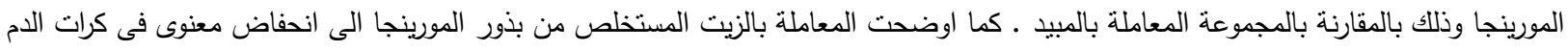

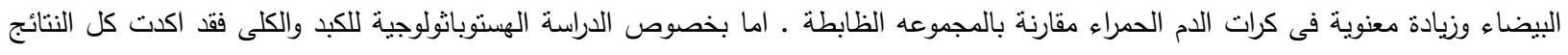
السابقة المتحصل عليها.

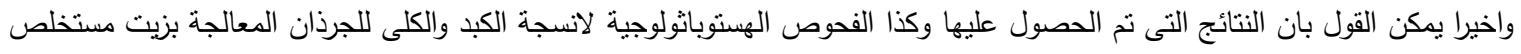

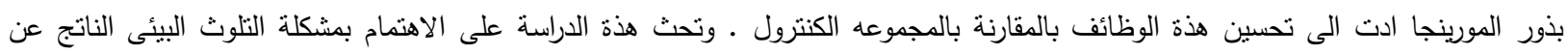

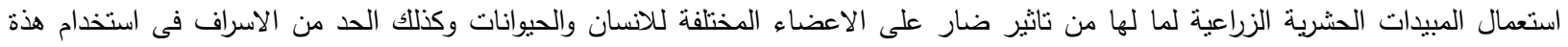

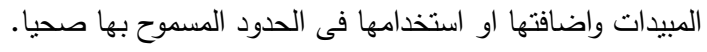

